\title{
Synthesis and RP HPLC studies of biologically active semicarbazides and their cyclic analogues 1,2,4-triazol-3-ones
}

\author{
Monika Pitucha · Joanna Matysiak • \\ Bogdan Senczyna
}

Received: 30 August 2011/Accepted: 28 December 2011/Published online: 28 January 2012

(C) The Author(s) 2012. This article is published with open access at Springerlink.com

\begin{abstract}
The retention behaviour of semicarbazides and their cyclic analogues 1,2,4-triazol-3-ones, has been investigated by RP-8, RP-18 and IAM HPLC. The structures of new derivatives were proved by elemental analyses, IR, ${ }^{1} \mathrm{H}$ NMR and ${ }^{13} \mathrm{C}$ NMR spectroscopy. The compounds showed regular retention behaviour in three chromatographic systems; their $\log k$ values decreased linearly with the increasing concentration of an organic modifier in the mobile phase. The ratio of the intercept $\left(\log k_{\mathrm{w}}\right)$ to the slope of compounds is constant and the same for both groups of compounds on C18 and IAM stationary phases. Differences between $\log k_{\mathrm{w}}$ values from the octadecyl stationary phase of corresponding cyclic and linear derivatives are constant, and they are related to the mechanism of synthesis of 1,2,4-triazol-3-ones from linear substrate semicarbazides, which was confirmed by modelling studies. Good correlations between $\log k_{\mathrm{w}}$ parameters obtained by RP- 8 or RP- 18 and determined by the computational approach $\log P$ were found.
\end{abstract}

Keywords Semicarbazide $\cdot$ 1,2,4-Triazol-3-one · RP HPLC · IAM chromatography · Lipophilicity

\section{Introduction}

Triazoles and their heterocyclic derivatives represent an interesting class of compounds possessing a wide spectrum

\footnotetext{
M. Pitucha $(\square)$

Department of Organic Chemistry,

Medical University of Lublin, Lublin, Poland

e-mail: monika.pitucha@umlub.pl

J. Matysiak · B. Senczyna

Department of Chemistry, University of Life Sciences in Lublin, Lublin, Poland
}

of biological activities [1-4], including antibacterial ones $[5,6]$. Examples of drugs bearing the 1,2,4-triazole residue are the powerful azole antifungal agent fluconazole [7], as well as the potent antiviral $N$-nucleoside ribavirin [8].

Their linear analogues, semicarbazides, commonly applied in the 1,2,4-triazole synthesis, are also an important class of compounds of diverse biological properties. They have been studied as anticonvulsant [9], antitubercular [10] and antinociceptive [11] agents. Additionally, the derivatives having the heterocyclic ring exhibit antibacterial activity, inhibiting growth of some gram-positive bacteria, including B. cereus and M. luteus [12]. Some of them show antinociceptive activity in a wide range of doses [13].

It is commonly known that biological activity of compounds is a function of their lipophilicity. Reversed phase (RP) chromatographic methods have been extensively applied to determine this property of many bioactive compounds [14, 15]. The use of alkyl-bonded phases in liquid chromatography offers a convenient and highly accurate method for the evaluation of the lipophilicity of a large variety of compounds [16, 17]. As the HPLC stationary phase for the determination of phase affinity of compounds, the immobilized artificial membrane (IAM) is also used [18-20].

A linear relationship between the retention parameters $(\log k)$ and the concentration $(\varphi)$ of organic modifier (acetonitrile, methanol, or others) in the aqueous mobile phase described by the Soczewiński-Wachtmeister equation (Eq. 1) has to be established for a successful chromatographic measurement of lipophilicity [21, 22].

$\log k=\log k_{\mathrm{w}}+S \varphi$

$\log k_{\mathrm{w}}$ represents the retention factor of a solute with pure water as the mobile phase; $S$ is the slope of the regression curve. This dependence allows for the extrapolation from 
the data obtained for the water-organic modifier to water as the mobile phase. On the basis of $\log k=\mathrm{f}(\varphi)$ relationships, the lipophilicity parameter $\log k_{\mathrm{w}}$ and the specific hydrophobic surface area $S$ can be calculated. Lipophilicity chromatographic descriptors obtained in this way help explain differences in the bioactivity of similar structure derivatives. They are usually used for QSAR model building, prediction of biological activity of new structure related analogues, and design and synthesis of more effective new derivatives [23, 24].

In this work comparable chromatographic studies of biologically active mono- and bis-1,2,4-triazol-3-ones as well as their linear analogues, semicarbazides, were carried out. The octyl, octadecyl and IAM stationary phases were used. To explain differences in the retention behaviour of compounds of both groups, molecular modeling was performed. $\log P$ values obtained from the computational approach were used comparatively.

\section{Results and discussion}

The structures of compounds under consideration are presented in Scheme 1. They include linear semicarbazides

Scheme 1
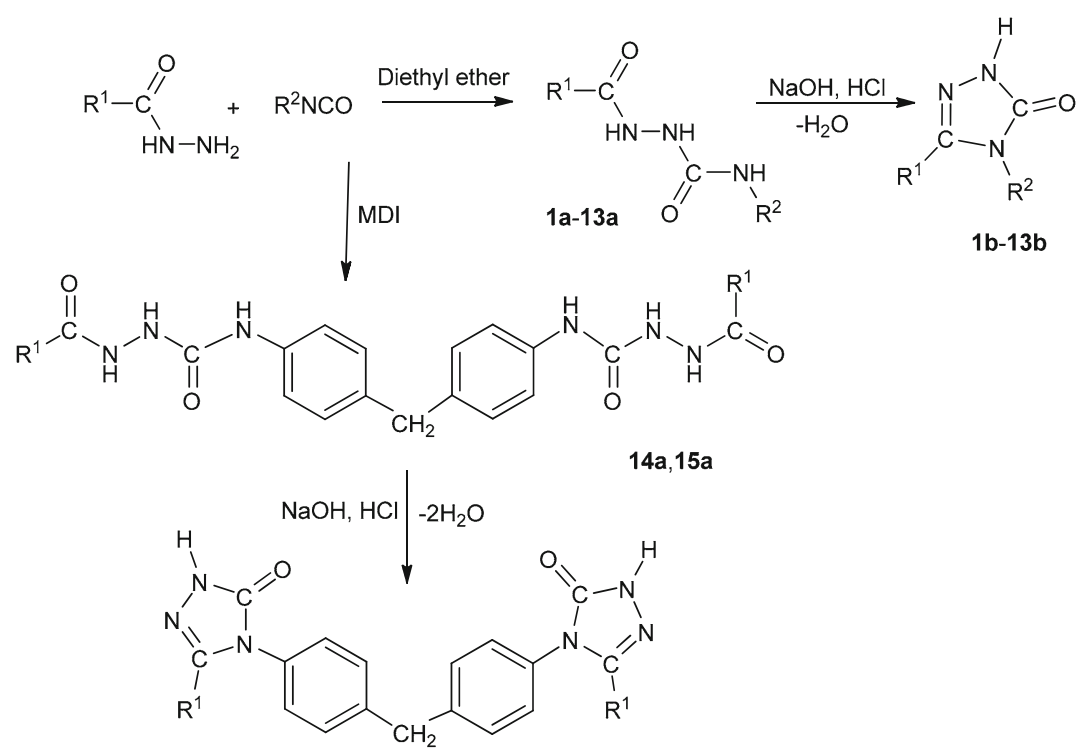

$14 b, 15 b$

\begin{tabular}{|c|c|c|c|c|c|}
\hline & $\mathrm{R}^{1}$ & $\mathrm{R}^{2}$ & & $\mathrm{R}^{1}$ & $\mathrm{R}^{2}$ \\
\hline $1 a, 1 b$ & & $4-\mathrm{C}_{2} \mathrm{H}_{5} \mathrm{OC}_{6} \mathrm{H}_{4}-$ & $9 a, 9 b$ & & $\mathrm{CH}_{2}=\mathrm{CHCH}_{2}-$ \\
\hline $2 a, 2 b$ & & $4-\mathrm{BrC}_{6} \mathrm{H}_{4}-$ & $10 a, 10 b$ & & $\mathrm{CH}_{2}=\mathrm{CHCH}_{2}-$ \\
\hline $3 a, 3 b$ & & $\mathrm{C}_{2} \mathrm{H}_{5-}$ & $11 a, 11 b$ & & Cyclohexyl- \\
\hline $4 a, 4 b$ & & $\mathrm{C}_{6} \mathrm{H}_{5} \mathrm{CH}_{2-}$ & $12 a, 12 b$ & & $4-\mathrm{C}_{2} \mathrm{H}_{5} \mathrm{OC}_{6} \mathrm{H}_{4}-$ \\
\hline $5 a, 5 b$ & & $\mathrm{CH}_{2}=\mathrm{CHCH}_{2-}$ & $13 a, 13 b$ & $\mathrm{C}_{6} \mathrm{H}_{5} \mathrm{CH}_{2-}$ & $\mathrm{CH}_{2}=\mathrm{CHCH}_{2^{-}}$ \\
\hline $6 a, 6 b$ & & $\mathrm{C}_{6} \mathrm{H}_{5^{-}}$ & $14 a, 14 b$ & $\mathrm{CH}_{3-}^{-}$ & \\
\hline $7 a, 7 b$ & & 4- $\mathrm{CH}_{3} \mathrm{C}_{6} \mathrm{H}_{4^{-}}$ & $15 a, 15 b$ & $\mathrm{C}_{2} \mathrm{H}_{5-}$ & \\
\hline $8 a, 8 b$ & & $\mathrm{C}_{2} \mathrm{H}_{5}-$ & & & \\
\hline
\end{tabular}


(a) and their cyclic analogues 3H-1,2,4-triazol-3-ones (b). The compounds of structure $\mathbf{b}$ were obtained by condensation reaction of $\mathbf{a}$ in alkaline medium. The process of water molecule elimination from compounds 1a-13a or two molecules from 14a and 15a gives the corresponding 3H-1,2,4-triazol-3-ones $\mathbf{1 b}-\mathbf{1 5} \mathbf{b}$.

The substitution panel of compounds under consideration includes heterocyclic, aryl, alkyl and alkenyl groups. The structures of new derivatives were proved by elemental analyses, IR, ${ }^{1} \mathrm{H}$ NMR and ${ }^{13} \mathrm{C}$ NMR spectroscopy.

The UV-Vis spectra in water-methanol solutions of different $\mathrm{pH}$ of compounds $\mathbf{1 3 \mathbf { a }}$ and $\mathbf{1 3 b}$ are presented in Fig. 1. They show that there are no significant changes in their electronic structure at $\mathrm{pH} 2-8$. As $\mathrm{pH} 7.4$ (physiological) is recommended for IAM chromatography measurements, for comparison all chromatographic experiments were performed at this $\mathrm{pH}$.

The $\log k$ values of compounds were determined using C-8, C-18 and IAM stationary phases. The mobile phases
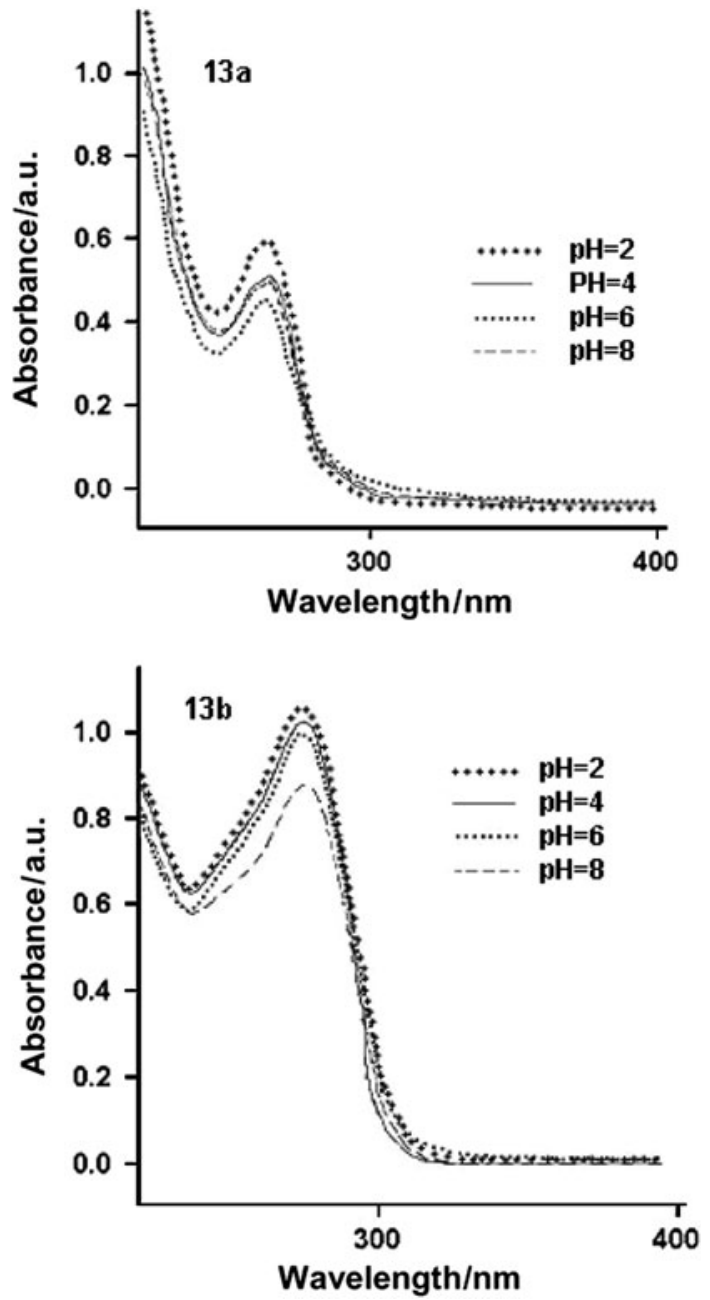

Fig. 1 UV-Vis spectra of compounds 13a and $13 \mathbf{b}$ in methanolwater solution of different $\mathrm{pH}$ consisted of buffer mixed with various amounts of methanol or acetonitrile to give $\mathrm{pH}$ 7.4. Linear relationships were obtained between the $\log k$ and $\varphi$ in the mobile phase in the whole studied ranges for all stationary phases. Generally, for semicarbazide derivatives and IAM chromatography, a larger content of water in the mobile phase can be used (Tables 1, 2). For some compounds $\log k_{\mathrm{w}}$ values on IAM were determined experimentally. The chromatograms of compound 12a are shown in Fig. 2.

The equations of the straight lines and statistics for three techniques are reported in Tables 1 and 2. As follows from the tables the absolute values of the slopes $|S|$ are the highest for the IAM stationary phase for both semicarbazides and $3 H$-1,2,4-triazol-3-ones. In the case of RP-8 and RP-18 chromatography, the $\log k_{\mathrm{w}}$ values for the linear structures (1a-15a) are lower than for the cyclic ones $(\mathbf{1 b}-\mathbf{1 5} \mathbf{b})$.

Biagi et al. [25] found that for closely congeneric compounds, the ratio of the intercept $\left(\log k_{\mathrm{w}}\right)$ to the slope $(S)$ in Eq. 1 is constant. The relationships between these parameters of semicarbazides (a) for RP-8, 18 and IAM chromatography are expressed by the following equations:

$$
\begin{aligned}
& \log k_{\mathrm{w}(\mathrm{C} 8(\mathbf{a}))}=0.774( \pm 0.106)(-S)_{\mathrm{C} 8(\mathbf{a})} \\
& -1.295( \pm 0.383) \quad n=15, r=0.896 \text {, } \\
& s=0.266, F=52.9, d f(1.13) \\
& \log k_{\mathrm{w}(\mathrm{C} 18(\mathbf{a}))}=0.928( \pm 0.031)(-S)_{\mathrm{C} 18(\mathbf{a})} \\
& -0.940( \pm 0.049) \quad n=15, r=0.992 \text {, } \\
& s=0.066, F=918.3, d f(1.13) \\
& \log k_{\mathrm{w}(\operatorname{IAM}(\mathbf{a}))}=0.407( \pm 0.051)(-S)_{\operatorname{IAM}(\mathbf{a})} \\
& -0.927( \pm 0.233) \quad n=15, r=0.911 \text {, } \\
& s=0.284, F=63.3, d f(1.13) \text {. }
\end{aligned}
$$

In the case of their cyclic analogues $3 H$-1,2,4-triazol-3ones (b), these relations are described by Eqs. 5-7:

$$
\begin{aligned}
& \log k_{\mathrm{w}(\mathrm{C} 8(\mathbf{b}))}=0.547( \pm 0.065)(-S)_{\mathrm{C} 8(\mathbf{b})} \\
& -0.288( \pm 0.286) \quad n=15, r=0.918, \\
& s=0.272, F=69.9, d f(1.13) \\
& \log k_{\mathrm{w}(\mathrm{C} 18(\mathbf{b}))}=0.921( \pm 0.064)(-S)_{\mathrm{C} 18(\mathbf{b})} \\
& -0.963( \pm 0.145) \quad n=15, r=0.969, \\
& s=0.127, F=205.3, d f(1.13) \\
& \log k_{\mathrm{w}(\operatorname{IAM}(\mathbf{b}))}=0.387( \pm 0.074)(-S)_{\operatorname{IAM}(\mathbf{b})} \\
& -0.928( \pm 0.395) \quad n=15, r=0.821 \text {, } \\
& s=0.313, F=27.1, d f(1.13) \text {. }
\end{aligned}
$$

The best results were obtained for the C-18 stationary phase (Eqs. 3, 6). However, in all cases congenerity of compounds was confirmed. The slopes of Eqs. 2 and 5, 3 and 6 , as well as 4 and 7 are similar. This may indicate the 
Table 1 Chromatographic parameters: $\log k_{\mathrm{w}}$ (intercept) and $-S$ (slope) of the linear dependences in Eq. 1 obtained by RP- 8 and RP-18 chromatography

\begin{tabular}{|c|c|c|c|c|c|c|c|c|c|c|}
\hline & \multicolumn{5}{|c|}{ RP-8 HPLC } & \multicolumn{5}{|c|}{ RP-18 HPLC } \\
\hline & $-S$ & Intercept & $r^{2}$ & $\varphi \mathrm{MeOH}$ & $n$ & $-S$ & Intercept & $r^{2}$ & $\varphi \mathrm{MeOH}$ & $n$ \\
\hline $1 \mathbf{a}$ & 3.978 & 1.946 & 0.970 & $0.70-0.25$ & 7 & 1.880 & 0.783 & 0.982 & $0.75-0.35$ & 7 \\
\hline $2 \mathbf{a}$ & 3.847 & 2.144 & 0.979 & $0.70-0.35$ & 5 & 2.279 & 1.279 & 0.981 & $0.75-0.35$ & 7 \\
\hline $3 \mathbf{a}$ & 3.449 & 1.022 & 0.984 & $0.70-0.20$ & 6 & 1.155 & 0.089 & 0.984 & $0.75-0.35$ & 7 \\
\hline $4 \mathbf{a}$ & 3.728 & 1.717 & 0.981 & $0.70-0.25$ & 7 & 2.065 & 0.871 & 0.982 & $0.75-0.30$ & 8 \\
\hline $5 a$ & 2.967 & 0.797 & 0.991 & $0.55-0.10$ & 9 & 0.910 & -0.074 & 0.901 & $0.75-0.30$ & 7 \\
\hline $6 \mathbf{a}$ & 3.371 & 1.563 & 0.992 & $0.70-0.20$ & 7 & 1.959 & 0.864 & 0.992 & $0.75-0.30$ & 7 \\
\hline $7 \mathbf{a}$ & 4.872 & 2.443 & 0.984 & $0.55-0.30$ & 6 & 2.365 & 1.280 & 0.960 & $0.75-0.35$ & 6 \\
\hline $8 \mathbf{a}$ & 2.919 & 0.799 & 0.991 & $0.70-0.10$ & 9 & 0.987 & 0.014 & 0.984 & $0.75-0.30$ & 7 \\
\hline $9 a$ & 2.948 & 0.721 & 0.990 & $0.70-0.10$ & 9 & 1.257 & 0.155 & 0.972 & $0.75-0.30$ & 7 \\
\hline 10a & 2.293 & 0.581 & 0.990 & $0.70-0.10$ & 9 & 0.854 & -0.154 & 0.907 & $0.75-0.30$ & 7 \\
\hline 11a & 3.725 & 1.783 & 0.977 & $0.70-0.30$ & 6 & 1.452 & 0.479 & 0.934 & $0.75-0.30$ & 7 \\
\hline $12 \mathbf{a}$ & 3.422 & 1.682 & 0.985 & $0.70-0.25$ & 7 & 1.506 & 0.471 & 0.857 & $0.75-0.30$ & 7 \\
\hline 13a & 3.386 & 1.234 & 0.992 & $0.70-0.10$ & 9 & 1.451 & 0.446 & 0.988 & $0.75-0.35$ & 6 \\
\hline $14 a$ & 4.398 & 1.705 & 0.970 & $0.70-0.20$ & 8 & 0.590 & -0.352 & 0.949 & $0.75-0.30$ & 7 \\
\hline $15 a$ & 4.401 & 1.998 & 0.930 & $0.70-0.25$ & 7 & 1.406 & 0.270 & 0.953 & $0.75-0.30$ & 6 \\
\hline 1b & 4.140 & 2.350 & 0.972 & $0.70-0.35$ & 5 & 2.392 & 1.341 & 0.963 & $0.75-0.40$ & 6 \\
\hline $2 b$ & 4.153 & 2.434 & 0.978 & $0.70-0.35$ & 5 & 2.623 & 1.545 & 0.965 & $0.75-0.40$ & 6 \\
\hline $3 \mathbf{b}$ & 3.301 & 1.324 & 0.973 & $0.70-0.20$ & 7 & 1.353 & 0.335 & 0.973 & $0.75-0.35$ & 7 \\
\hline $4 b$ & 3.841 & 2.139 & 0.974 & $0.70-0.25$ & 5 & 2.507 & 1.439 & 0.964 & $0.75-0.40$ & 6 \\
\hline $5 b$ & 3.539 & 1.550 & 0.981 & $0.55-0.20$ & 7 & 1.591 & 0.540 & 0.931 & $0.75-0.30$ & 7 \\
\hline $6 \mathbf{b}$ & 3.601 & 1.987 & 0.975 & $0.80-0.30$ & 7 & 2.670 & 1.514 & 0.975 & $0.75-0.40$ & 6 \\
\hline $7 b$ & 5.124 & 2.893 & 0.959 & $0.70-0.40$ & 6 & 3.268 & 2.069 & 0.965 & $0.75-0.40$ & 6 \\
\hline $\mathbf{8 b}$ & 3.637 & 1.661 & 0.980 & $0.70-0.20$ & 8 & 1.758 & 0.745 & 0.892 & $0.75-0.35$ & 7 \\
\hline $9 b$ & 3.417 & 1.551 & 0.979 & $0.70-0.20$ & 8 & 1.757 & 0.758 & 0.995 & $0.75-0.30$ & 7 \\
\hline 10b & 2.711 & 0.874 & 0.975 & $0.70-0.10$ & 9 & 1.767 & 0.36 & 0.853 & $0.75-0.30$ & 7 \\
\hline 11b & 4.591 & 2.172 & 0.981 & $0.70-0.30$ & 6 & 1.905 & 0.862 & 0.985 & $0.75-0.30$ & 7 \\
\hline $12 b$ & 4.829 & 2.244 & 0.981 & $0.70-0.30$ & 6 & 2.331 & 0.977 & 0.899 & $0.75-0.30$ & 7 \\
\hline 13b & 3.793 & 1.923 & 0.973 & $0.70-0.30$ & 6 & 2.211 & 1.126 & 0.925 & $0.75-0.30$ & 6 \\
\hline 14b & 6.725 & 3.038 & 0.979 & $0.70-0.30$ & 6 & 1.974 & 0.792 & 0.991 & $0.75-0.30$ & 7 \\
\hline 15b & 6.305 & 3.311 & 0.954 & $0.70-0.35$ & 5 & 2.821 & 1.531 & 0.902 & $0.75-0.30$ & 7 \\
\hline
\end{tabular}

same retention mechanism of both studied compounds in these chromatographic systems. The relationships between the intercept $\left(\log k_{\mathrm{w}}\right)$ and the slope $(-S)$ of both groups of compounds for three chromatographic systems are presented in Figs. 3, 4 and 5.

They are expressed by the following equations:

$$
\begin{aligned}
\log k_{\mathrm{w}(\mathrm{C} 8(\mathbf{a}, \mathbf{b}))=} & 0.648( \pm 0.057)(-S)_{\mathrm{C} 8(\mathbf{a}, \mathbf{b})} \\
& -0.750( \pm 0.048) \quad n=30, r=0.907, \\
s= & 0.294, F=130.2, d f(1.28)
\end{aligned}
$$

$\log k_{\mathrm{w}(\mathrm{C} 18(\mathbf{a}, \mathbf{b}))}=0.901( \pm 0.028)(-S)_{\mathrm{C} 18(\mathbf{a}, \mathbf{b})}$

$$
\begin{aligned}
& -0.924( \pm 0.048) \quad n=30, r=0.987 \\
s= & 0.097, F=1,040.2, d f(1.28)
\end{aligned}
$$

$$
\begin{aligned}
\log k_{\mathrm{w}(\operatorname{IAM}(\mathbf{a}, \mathbf{b}))}= & 0.373( \pm 0.035)(-S)_{\operatorname{IAM}(\mathbf{a}, \mathbf{b})} \\
& -0.857( \pm 0.172) \quad n=28, r=0.902, \\
s= & 0.256, F=113.2, d f(1.26) .
\end{aligned}
$$

Compounds $\mathbf{2 a}$ and $\mathbf{2 b}$ are outliers in IAM chromatography. The equations show that semicarbazides and corresponding 3H-1,2,4-triazol-3-ones are a set of congeneric compounds [25, 26]. Therefore, they were analyzed together during further studies.

The relationships between the $\log k_{\mathrm{w}}$ values obtained by different chromatographic techniques are not very powerful. It can be assumed that compounds 14 and 15 (with two semicarbazide moieties or two triazole rings) are outliers. Under this assumption, the relationships 
Table 2 Chromatographic parameters: $\log k_{\mathrm{w}}$ (intercept) and $-S$ (slope) of the linear dependences in Eq. 1 obtained by IAM chromatography and $\log P$ values

\begin{tabular}{llllllr}
\hline & \multicolumn{2}{l}{ IAM HPLC } & & & & $\log P$ \\
\cline { 2 - 5 } & $-S$ & Intercept & $r^{2}$ & $\varphi$ ACN & $n$ & \\
\hline 1a & 5.094 & 1.257 & 0.995 & $0.30-0.05$ & 6 & 0.91 \\
2a & 5.358 & 1.847 & 0.993 & $0.30-0.10$ & 5 & 1.53 \\
3a & 3.514 & 0.067 & 0.901 & $0.40-0.15$ & 6 & -0.63 \\
4a & 4.077 & 0.825 & 0.997 & $0.30-0.00$ & 7 & 0.77 \\
5a & 2.458 & 0.097 & 0.955 & $0.25-0.00$ & 6 & -0.27 \\
6a & 4.626 & 1.230 & 0.995 & $0.50-0.15$ & 8 & 1.90 \\
7a & 5.061 & 1.522 & 0.995 & $0.30-0.05$ & 6 & 2.39 \\
8a & 2.453 & 0.003 & 0.868 & $0.30-0.00$ & 7 & 0.58 \\
9a & 2.783 & 0.101 & 0.993 & $0.30-0.00$ & 7 & 0.09 \\
10a & 2.581 & 0.206 & 0.965 & $0.30-0.00$ & 7 & -0.39 \\
11a & 5.227 & 1.137 & 0.997 & $0.30-0.05$ & 6 & 0.47 \\
12a & 4.588 & 0.740 & 0.993 & $0.30-0.00$ & 7 & 0.79 \\
13a & 3.318 & 0.318 & 0.986 & $0.30-0.00$ & 6 & 0.95 \\
14a & 6.727 & 1.459 & 0.998 & $0.30-0.05$ & 6 & 0.21 \\
15a & 7.091 & 1.725 & 0.996 & $0.30-0.05$ & 6 & 1.52 \\
1b & 5.878 & 1.543 & 0.996 & $0.30-0.05$ & 6 & 2.04 \\
2b & 5.519 & 1.705 & 0.996 & $0.30-0.10$ & 5 & 2.65 \\
3b & 4.228 & 0.441 & 0.985 & $0.40-0.15$ & 6 & 0.50 \\
4b & 5.211 & 1.391 & 0.998 & $0.30-0.05$ & 6 & 1.90 \\
5b & 4.062 & 0.513 & 0.995 & $0.30-0.00$ & 7 & 0.85 \\
6b & 4.761 & 1.243 & 0.998 & $0.50-0.15$ & 8 & 3.03 \\
7b & 5.900 & 1.760 & 0.997 & $0.30-0.10$ & 5 & 3.52 \\
8b & 4.274 & 0.712 & 0.995 & $0.30-0.00$ & 7 & 1.70 \\
9b & 3.782 & 0.584 & 0.908 & $0.30-0.00$ & 7 & 1.22 \\
10b & 3.994 & 0.158 & 0.998 & $0.30-0.00$ & 7 & 0.74 \\
11b & 5.374 & 0.985 & 0.986 & $0.30-0.05$ & 6 & 1.59 \\
12b & 5.924 & 1.056 & 0.994 & $0.30-0.00$ & 7 & 1.92 \\
13b & 4.593 & 0.935 & 0.996 & $0.30-0.00$ & 7 & 2.08 \\
14b & 6.902 & 1.322 & 0.994 & $0.30-0.05$ & 6 & 2.47 \\
15b & 7.684 & 1.913 & 0.997 & $0.30-0.10$ & 5 & 3.78 \\
\hline & & & & & &
\end{tabular}

between the intercepts $\left(\log k_{\mathrm{w}}\right)$ are described in the following way:

$$
\begin{aligned}
\log k_{\mathrm{w}(\mathrm{C} 18(\mathbf{a}, \mathbf{b}))=} & 0.853( \pm 0.071) \log k_{\mathrm{w}(\mathrm{C} 8(\mathbf{a}, \mathbf{b}))} \\
& -0.654( \pm 0.126) \quad n=26, r=0.926, \\
s= & 0.218, F=144.5, d f(1.24)
\end{aligned}
$$

$\log k_{\mathrm{w}(\mathrm{C} 18(\mathbf{a}, \mathbf{b}))}=0.692( \pm 0.102) \log k_{\mathrm{w}(\operatorname{IAM}(\mathbf{a}, \mathbf{b}))}$

$$
\begin{aligned}
& +0.563( \pm 0.094) \quad n=26, r=0.902, \\
s= & 0.249, F=105.1, d f(1.24)
\end{aligned}
$$

$\log k_{\mathrm{w}(\mathrm{C} 8(\mathbf{a}, \mathbf{b}))}=0.979( \pm 0.083) \log k_{\mathrm{w}(\operatorname{IAM}(\mathbf{a}, \mathbf{b}))}$

$$
\begin{aligned}
& +0.832( \pm 0.085) \quad n=26, r=0.924, \\
s= & 0.240, F=139.9, d f(1.24) .
\end{aligned}
$$

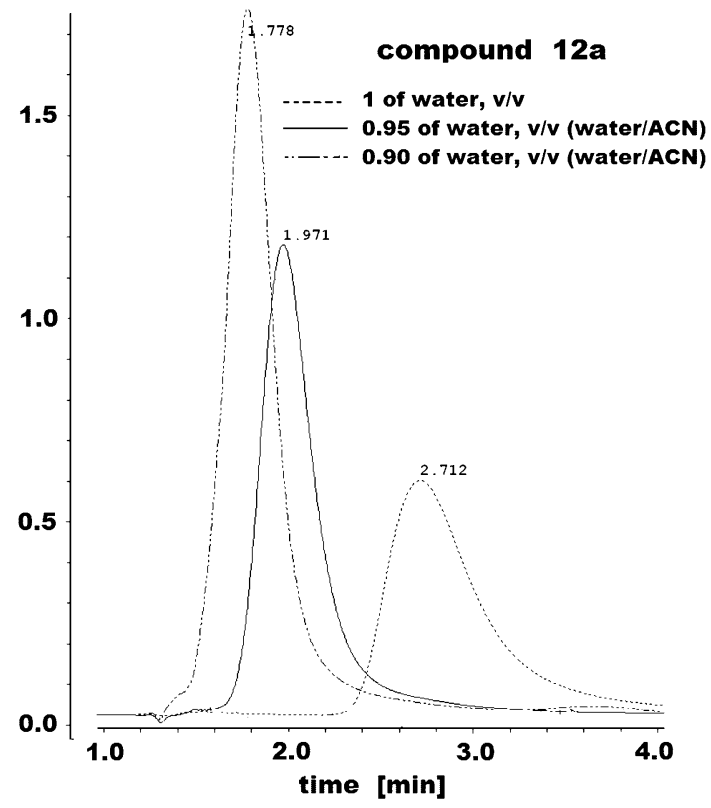

Fig. 2 Chromatograms of compound 12a obtained by IAM chromatography for different water contents in water/ACN mobile phase

The weakest correlation was found between the most hydrophobic phase and the most polar one (Eq. 12).

For comparison, the theoretical values of $\log P$ were calculated according to the fragmentation method introduced by Crippen [27]. The analysis of both groups of compounds gives the following equation:

$\log k_{\mathrm{w}(\mathrm{C} 18)}=0.451( \pm 0.058) \log P+0.105( \pm 0.106)$

$n=26, r=0.937, s=0.201, F=174.1, d f(1.24)$

$\log k_{\mathrm{w}(\mathrm{C} 8)}=0.533( \pm 0.059) \log P+1.061( \pm 0.106)$

$$
n=30, r=0.862, s=0.355, F=81.0, d f(1.28) \text {. }
$$

Compounds $\mathbf{1 4}$ and $\mathbf{1 5}$ are outliers in Eq. 14. In the case of IAM chromatography very poor correlation was obtained ( $r=0.753, n=30)$.

Markedly different chromatographic behaviour of solutes on the IAM chromatography is a result of some differences in the stationary phase structure [28]. Generally, the correlation between the logarithms of the retention factor determined on the IAM columns $\log k_{\mathrm{w}(\mathrm{IAM})}$ and the reference parameter of hydrophobicity, $\log D$ as well as $\log$ $k_{\mathrm{w}(\mathrm{C} 18)}(\log P)$ is not large [29]. However, the $\log k_{\mathrm{w}(\mathrm{IAM})}$ values appeared to be a better predictor of bioactivity than $\log D$ for several classes of drugs [29, 30].

As the transformation of semicarbazides into $3 \mathrm{H}-1,2,4-$ triazol-3-ones is associated with the elimination of water, the differences between $\log k_{\mathrm{w}(\mathrm{b})}$ and $\log k_{\mathrm{w}(\mathrm{a})}$ values, $\Delta \log$ $k_{\mathrm{w}}$, were calculated. Table 3 shows that the lipophilicity differences between the corresponding derivatives in RP-18 
Fig. 3 Relationship between the intercept $\left(\log k_{\mathrm{w}}\right)$ and slopes $(-S)$ of both groups of compounds (a and b) obtained by RP- 8 stationary phase (Eq. 8)
Fig. 4 Relationship between the intercept $\left(\log k_{\mathrm{w}}\right)$ and slopes $(-S)$ of both groups of compounds (a and b) obtained by RP-18 stationary phase (Eq. 9)
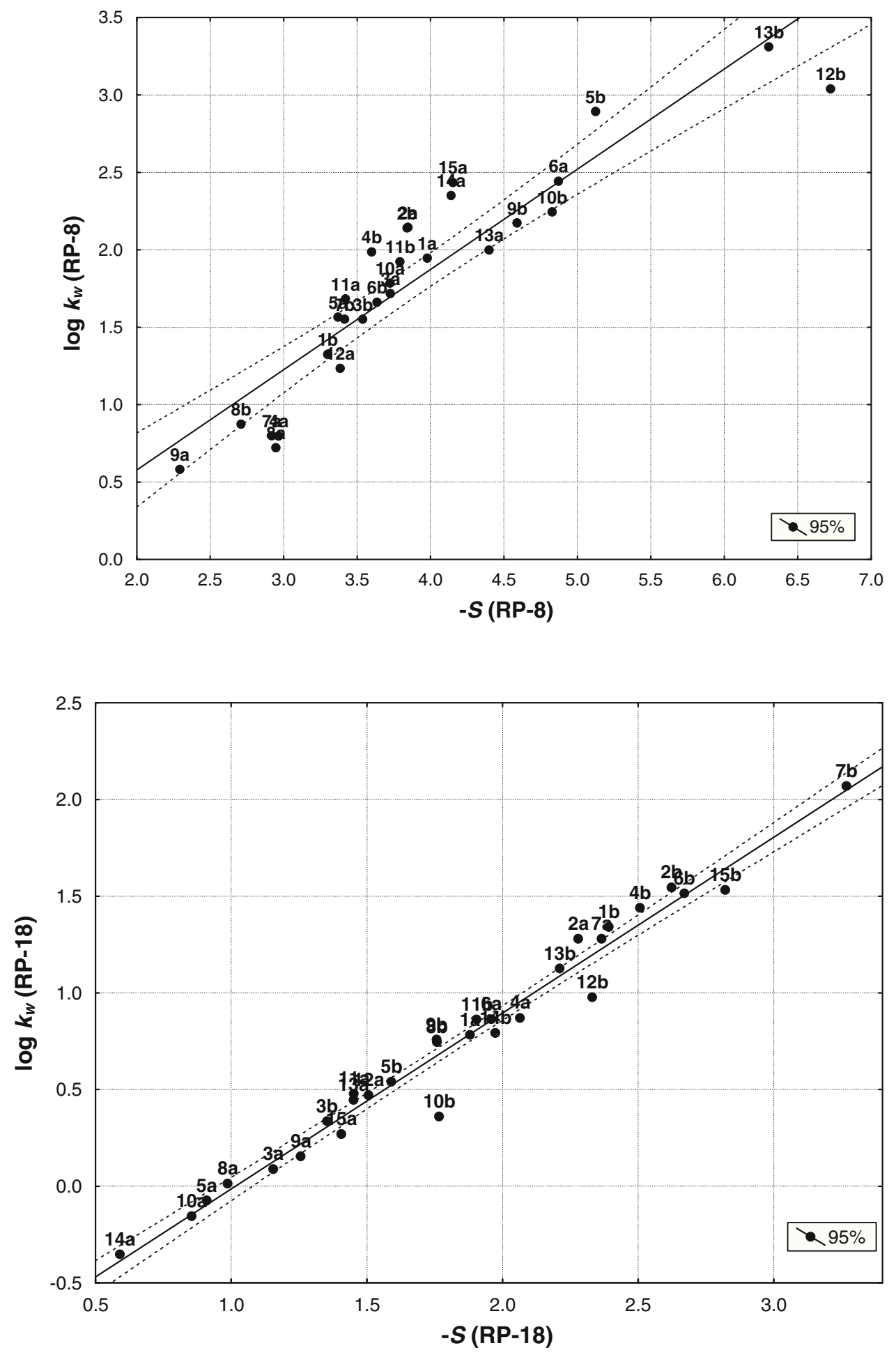

chromatography, $\Delta \log k_{\mathrm{w}(\mathrm{C} 18)}$, are in the range about 0.5-0.7. Higher values (about 1.2) for compounds 14 and 15 were found. They are formed by the elimination of two water molecules from the linear substrates (Scheme 1), so the lipophilicity differences are about twice as large. A similar trend for RP-8 chromatography was observed (Table 3). This finding reflects the synthesis mechanism of compounds of structure $\mathbf{b}$ from $\mathbf{a}$. At the same time it shows that the elimination of water from a molecule reduces its lipophilicity as well as absolute values of the specific hydrophobic surface, and the ratio of the intercept $\left(\log k_{\mathrm{w}}\right)$ to the slope $(-S)$ of compounds is constant in both groups. The obtained results are in accordance with the fragmental method used for $\log P$ calculations [27]. The differences 
Fig. 5 Relationship between the intercept $\left(\log k_{\mathrm{w}}\right)$ and slopes $(-S)$ of both groups of compounds ( $\mathbf{a}$ and $\mathbf{b})$ obtained by IAM stationary phase (Eq. 10)

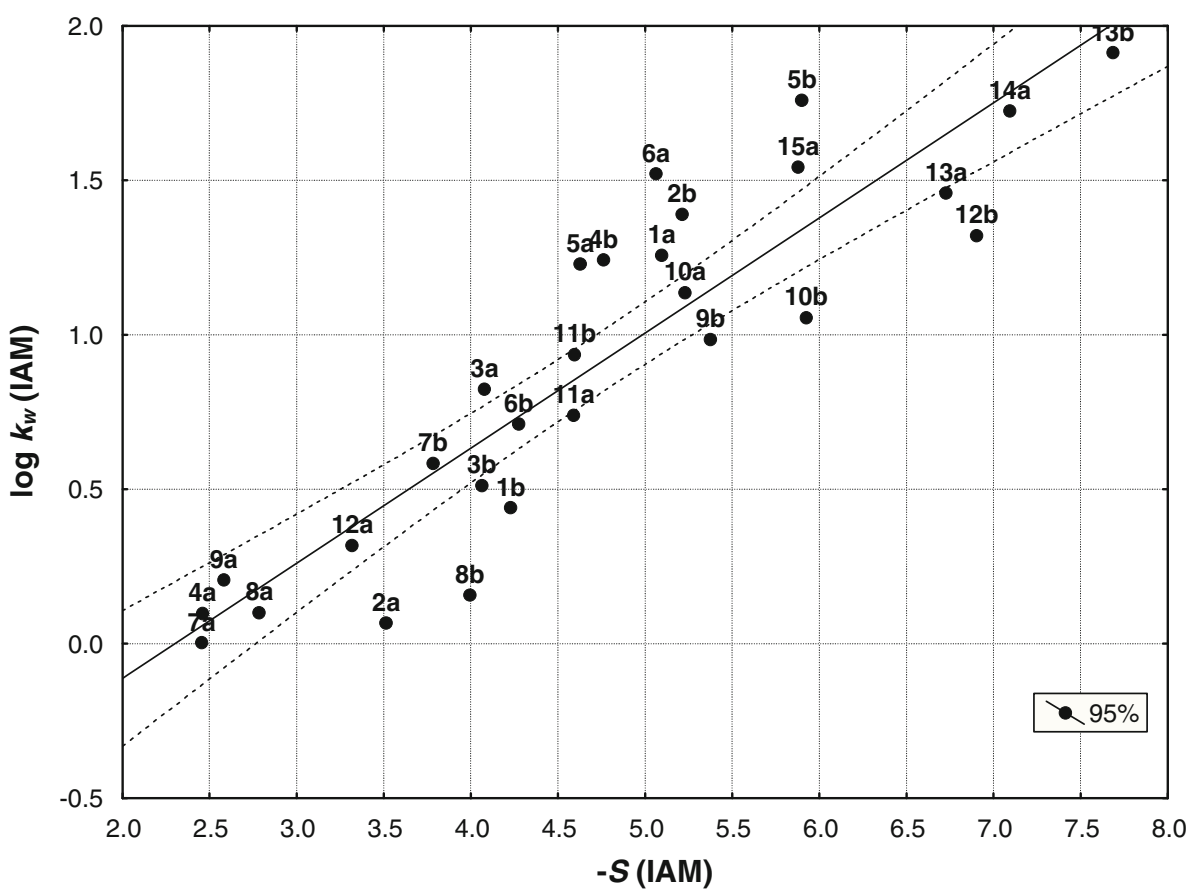

Table 3 The lipophilicity differences between the $3 H$-1,2,4-triazol3 -ones and the corresponding semicarbazides $\left(\Delta \log k_{\mathrm{w}}\right)$ obtained by different chromatographic systems

\begin{tabular}{lllc}
\hline & $\Delta \log k_{\mathrm{w}(8)}^{\mathrm{a}}$ & $\Delta \log k_{\mathrm{w}(\mathrm{C} 18)}^{\mathrm{b}}$ & $\Delta \log k_{\mathrm{w}(\mathrm{IAM})}^{\mathrm{c}}$ \\
\hline 1a,b & 0.404 & 0.558 & 0.286 \\
2a,b & 0.290 & 0.266 & -0.142 \\
3a,b & 0.301 & 0.246 & 0.373 \\
4a,b & 0.422 & 0.568 & 0.566 \\
5a,b & 0.754 & 0.614 & 0.415 \\
6a,b & 0.423 & 0.650 & 0.013 \\
7a,b & 0.450 & 0.789 & 0.238 \\
8a,b & 0.862 & 0.731 & 0.709 \\
9a,b & 0.830 & 0.603 & 0.483 \\
10a,b & 0.293 & 0.514 & -0.048 \\
11a,b & 0.389 & 0.383 & -0.152 \\
12a,b & 0.563 & 0.506 & 0.316 \\
13a,b & 0.689 & 0.680 & 0.617 \\
14a,b & 1.333 & 1.144 & -0.138 \\
15a,b & 1.313 & 1.261 & 0.189 \\
\hline
\end{tabular}

${ }^{\mathrm{a}} \Delta \log k_{\mathrm{w}(\mathrm{C} 8)}=\log k_{\mathrm{w}(\mathrm{C} 8(\mathbf{b}))}-\log k_{\mathrm{w}(\mathrm{C} 8(\mathbf{a}))}$

${ }^{\mathrm{b}} \Delta \log k_{\mathrm{w}(\mathrm{C} 18)}=\log k_{\mathrm{w}(\mathrm{C} 18(\mathbf{b}))}-\log k_{\mathrm{w}(\mathrm{C} 18(\mathbf{a}))}$

${ }^{\mathrm{c}} \Delta \log k_{\mathrm{w}(\mathrm{IAM})}=\log k_{\mathrm{w}(\operatorname{IAM}(\mathbf{b}))}-\log k_{\mathrm{w}(\operatorname{IAM}(\mathbf{a}))}$

between $\log P$ values of compound structures $\mathbf{b}$ and $\mathbf{a}$ are equal 1.13 (1.12) for analogues 1-13 and 2.26 for $\mathbf{1 4}$ and $\mathbf{1 5}$. The differences between the $\log k_{\mathrm{w}(\operatorname{IAM}(\mathbf{b}))}$ and $\log k_{\mathrm{w}(\operatorname{IAM}(\mathbf{a}))}$ values, $\Delta \log k_{\mathrm{w}(\mathrm{IAM})}$, are varied (Table 3 ).

To compare the structures of compounds quantum mechanical calculations were carried out with the semiempirical model at the PM3 basis set. In Fig. 6 compounds 7a and $7 \mathbf{b}$ are shown as representative analogues of the analysed groups.

As follows from Fig. 6 elimination of water from an a molecule remarkably changes its shape, flexibility and dipole moment, and decreases both the area and volume. Of course, changes of individual compounds are also a function of the substituents. The MEPs, the electrostatic potential profile of compounds, show that the most negative potential of compound structure $\mathbf{a}$ is located on four heteroatoms of the semicarbazide moiety (without taking the substituent into account). In the cyclic analogues $\mathbf{b}$ it covers mainly two oxygen atoms. The area and volume reduction of $\mathbf{b}$ compared to $\mathbf{a}$ is associated with reduction of the polar local area of molecules. It causes stronger interactions with the hydrophobic octadecyl or octyl stationary phases and increases lipophilicity.

In conclusion, new semicarbazides and corresponding 1,2,4-triazol-3-one derivatives have been synthesized. In RP-8, RP-18 and IAM chromatography, the dependences of $\log k$ versus the concentration of an organic modifier $(\varphi)$ in the mobile phase were linear. The constant ratio of the intercept $\left(\log k_{\mathrm{w}}\right)$ to the slope $(-S)$ of compounds showed that the compounds of both groups are congeneric according to Biagi. The differences in the retention behaviour of compounds of structures $\mathbf{b}$ and $\mathbf{a}$ in C-18 and C-8 chromatography reflect the synthesis method of 1,2,4-triazol-3-ones from linear substrates connected with the elimination of water from a molecule. The good correlation coefficient between the $\log k_{\mathrm{w}}$ values obtained by octadecyl and octyl phases suggests that these parameters can be used independently in the evaluation of compounds under consideration. 
$7 \mathbf{a}$

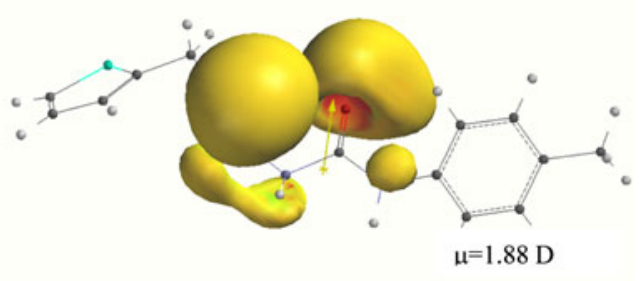

Area $=345.78 \AA^{2} ;$ volume $=322.67 \AA^{3}$

$7 \mathbf{b}$

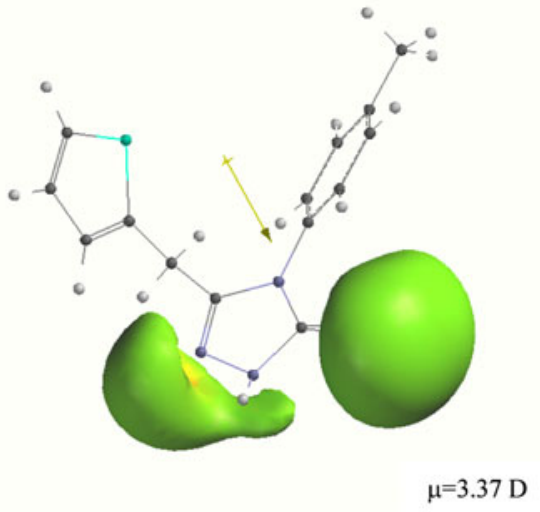

Area $=308.77 \AA^{2} ;$ volume $=297.01 \AA^{3}$

Fig. 6 Optimised structures of $7 \mathbf{a}$ and $7 \mathbf{b}$ and the MEPs of the electrostatic potential profile at $-84 \mathrm{~kJ} \mathrm{~mol}^{-1}$

\section{Experimental}

Melting points were determined in a Fisher-Johns block. Elemental analyses $(\mathrm{C}, \mathrm{H}, \mathrm{N})$ were conducted using an Elemental Analyser $\mathrm{CHN}$; their results were found to be in good agreement with the calculated values. IR spectra were recorded from $\mathrm{KBr}$ discs using a Specord IR-75 spectrophotometer. ${ }^{1} \mathrm{H}$ NMR spectra were recorded on a Bruker AC $300 \mathrm{~F}$ instrument $(300 \mathrm{MHz})$ in DMSO- $d_{6}$ with TMS as an internal standard. ${ }^{13} \mathrm{C}$ NMR spectra were recorded on a Bruker AC 250F instrument (62.5 MHz) in DMSO- $d_{6}$ with TMS as an internal standard. Chemicals were purchased from Alfa-Aesar or Merck. The purity of the obtained compounds was checked by TLC on aluminum oxide 60 $\mathrm{F}_{254}$ plates (Merck) in a $\mathrm{CHCl}_{3} / \mathrm{C}_{2} \mathrm{H}_{5} \mathrm{OH}$ (10:1 and 10:2) solvent system with UV or iodine visualization. Compounds 1-4, 6-8, 11a-13a and 14 were synthesized and characterized earlier [31-35].

\section{Synthesis of 1,4-disubstituted semicarbazides}

To $10 \mathrm{mmol}$ of appropriate carboxylic acid hydrazide dissolved in $10 \mathrm{~cm}^{3}$ of diethyl ether $10 \mathrm{mmol}$ isocyanate was added. The mixture was kept at room temperature for $24 \mathrm{~h}$. The precipitate was filtered and crystallized from ethanol.
1-Methyl-1H-pyrrole-2-acetic acid 2-[(2-propenylamino)carbonyl]hydrazide $\left(\mathbf{5 a}, \mathrm{C}_{11} \mathrm{H}_{16} \mathrm{~N}_{4} \mathrm{O}_{2}\right)$

Yield $1.96 \mathrm{~g}(83 \%)$; m.p.: $137-139{ }^{\circ} \mathrm{C}$; IR $(\mathrm{KBr})$ : $\bar{v}=3,279,3,192,3,034,1,701,1,649,1,444 \mathrm{~cm}^{-1} ;{ }^{1} \mathrm{H}$ NMR (300 MHz, DMSO- $\left.d_{6}\right): \delta=3.32(\mathrm{~s}, 2 \mathrm{H}), 3.52(\mathrm{~s}$, 3H), 3.61-3.65 (m, 2H), 4.98-5.15 (m, 2H), 5.72-5.84 (m, 1H), 6.85-7.63 (m, 3H, pyrrole-H), 7.63 (s, NH), $7.78(\mathrm{~s}$, $\mathrm{NH}), 9.60$ (s, NH) ppm; ${ }^{13} \mathrm{C}$ NMR $\left(62.5 \mathrm{MHz}, \mathrm{DMSO}-d_{6}\right)$ : $\delta=31.45\left(\mathrm{CH}_{2}\right), 33.52\left(\mathrm{CH}_{3}\right), 41.42\left(\mathrm{CH}_{2}\right), 106.01(\mathrm{CH})$, $107.84\left(\mathrm{C}_{\text {arom }}\right), 114.40\left(\mathrm{CH}_{2}\right), 121.82,126.09,136.28$ $\left(3 \times \mathrm{C}_{\text {arom }}\right), 157.91(\mathrm{C}=\mathrm{O}), 169.26(\mathrm{C}=\mathrm{O}) \mathrm{ppm}$.

Pyridine-2-carboxylic acid 2-[(2-propenylamino)carbonyl]hydrazide $\left(\mathbf{9 a}, \mathrm{C}_{10} \mathrm{H}_{12} \mathrm{~N}_{4} \mathrm{O}_{2}\right)$

Yield $1.76 \mathrm{~g}$ (80\%); m.p.: $195-197{ }^{\circ} \mathrm{C}$; IR $(\mathrm{KBr})$ : $\bar{v}=3,261,3,013,2,814,1,697,1,651,1,487 \mathrm{~cm}^{-1} ;{ }^{1} \mathrm{H}$ NMR (300 MHz, DMSO- $\left.d_{6}\right): \delta=3.63-3.72(\mathrm{~m}, 2 \mathrm{H})$, 4.98-5.18 (m, 2H), 5.71-5.86 (m, 1H), $6.59(\mathrm{~s}, \mathrm{NH})$, 7.56-8.08 (m, 4H, pyridine-H), $8.72(\mathrm{~s}, \mathrm{NH}), 10.26(\mathrm{~s}, \mathrm{NH})$ ppm; ${ }^{13} \mathrm{C}$ NMR $\left(62.5 \mathrm{MHz}, \mathrm{DMSO}-d_{6}\right): \delta=13.31\left(\mathrm{CH}_{2}\right)$, $61.74\left(\mathrm{CH}_{2}\right), 113.06(\mathrm{CH}), 123.12,130.03,143.23,148.01$, $152.48\left(5 \times \mathrm{C}_{\text {arom }}\right), 154.21(\mathrm{C}=\mathrm{O}), 167.73(\mathrm{C}=\mathrm{O}) \mathrm{ppm}$.

Pyridine-4-acetic acid 2-[(2-propenylamino)carbonyl]hydrazide (10a, $\mathrm{C}_{11} \mathrm{H}_{14} \mathrm{~N}_{4} \mathrm{O}_{2}$ )

Yield $1.62 \mathrm{~g}$ (69\%); m.p.: $130-131{ }^{\circ} \mathrm{C}$; IR (KBr): $\bar{v}=3,309,3,267,2,960,1,644,1,598,1,455 \mathrm{~cm}^{-1} ;{ }^{1} \mathrm{H}$ NMR (300 MHz, DMSO- $\left.d_{6}\right): \delta=3.49$ (s, 2H), 3.56-3.70 $(\mathrm{m}, 2 \mathrm{H}), 5.00-5.15(\mathrm{~m}, 2 \mathrm{H}), 5.72-5.85(\mathrm{~m}, 1 \mathrm{H}), 6.53(\mathrm{t}$, $J=5.6 \mathrm{~Hz}, \mathrm{NH}), 7.20-8.49$ (m, 4H, pyridine-H), 7.85 (s, $\mathrm{NH}), 9.82$ (s, NH) ppm; ${ }^{13} \mathrm{C}$ NMR (62.5 MHz, DMSO- $\left.d_{6}\right)$ : $\delta=40.00\left(\mathrm{CH}_{2}\right), 40.11\left(\mathrm{CH}_{2}\right), 113.12\left(\mathrm{CH}_{2}\right), 123.26$ $(\mathrm{CH}), 123.82,143.26,147.78,147.96\left(5 \times \mathrm{C}_{\text {arom }}\right), 156.62$ $(\mathrm{C}=\mathrm{O}), 167.68(\mathrm{C}=\mathrm{O}) \mathrm{ppm}$.

Propanoic acid 1,1'-[2,2'-[methylenebis(4,1-

phenyleneiminocarbonyl)]dihydrazide]

(15a, $\mathrm{C}_{21} \mathrm{H}_{26} \mathrm{~N}_{6} \mathrm{O}_{4}$ )

Yield $3.49 \mathrm{~g}(82 \%)$; m.p.: $356-358{ }^{\circ} \mathrm{C}$; IR (KBr): $\bar{v}=3,304,3,032,2,977,1,650,1,463 \mathrm{~cm}^{-1} ;{ }^{1} \mathrm{H} \mathrm{NMR}$ (300 MHz, DMSO- $\left.d_{6}\right): \delta=1.95-2.07(\mathrm{~m}, 6 \mathrm{H}), 2.10-2.35$ (m, 4H), 3.80 (s, 2H), 7.06-7.39 (m, 8H, phenyl-H), 7.90 $(\mathrm{s}, 2 \mathrm{NH}), 8.64(\mathrm{~s}, 2 \mathrm{NH}), 9.54(\mathrm{~s}, 2 \mathrm{NH}) \mathrm{ppm} ;{ }^{13} \mathrm{C} \mathrm{NMR}$ $\left(62.5 \mathrm{MHz}, \mathrm{DMSO}-d_{6}\right): \delta=7.01\left(2 \times \mathrm{CH}_{3}\right), 8.26(2 \times$ $\left.\mathrm{CH}_{2}\right), 25.06\left(\mathrm{CH}_{2}\right), 117.38,118.72,127.42,133.80,136.07$ $\left(12 \times \mathrm{C}_{\text {arom }}\right), 154.20(2 \times \mathrm{C}=\mathrm{O}), 170.80(2 \times \mathrm{C}=\mathrm{O}) \mathrm{ppm}$.

Synthesis of 4,5-disubstituted 2,4-dihydro-3H-1,2,4triazol-3-one derivatives

A mixture of $10 \mathrm{mmol}$ of semicarbazide derivatives a and $50 \mathrm{~cm}^{3}$ of $2 \%$ aqueous solution of sodium hydroxide was refluxed for $20 \mathrm{~h}$. After cooling, the solution was neutralized 
with dilute hydrochloric acid. The precipitate was filtered off and then crystallized from ethanol.

2,4-Dihydro-5-[(1-methyl-1H-pyrrol-2-yl)methyl]-4-(2propenyl)-3H-1,2,4-triazol-3-one $\left(\mathbf{5 b}, \mathrm{C}_{11} \mathrm{H}_{14} \mathrm{~N}_{4} \mathrm{O}\right)$

Yield $1.65 \mathrm{~g} \quad(76 \%)$; m.p.: $\quad 110-112{ }^{\circ} \mathrm{C}$; IR (KBr): $\bar{v}=3,283,3,088,3,015,2,854,1,697,1,647,1,461 \mathrm{~cm}^{-1}$; ${ }^{1} \mathrm{H}$ NMR (300 MHz, DMSO- $\left.d_{6}\right): \delta=3.49$ (s, 3H), 3.83 (s, $2 \mathrm{H}), 4.12-4.14(\mathrm{~m}, 2 \mathrm{H}), 4.92-5.13(\mathrm{~m}, 2 \mathrm{H}), 5.66-5.83(\mathrm{~m}$, $1 \mathrm{H}), 5.88-6.66\left(\mathrm{~m}, 3 \mathrm{H}\right.$, pyrrol-H), $11.52(\mathrm{~s}, \mathrm{NH}) \mathrm{ppm} ;{ }^{13} \mathrm{C}$ NMR $\left(62.5 \mathrm{MHz}\right.$, DMSO- $\left.d_{6}\right): \delta=22.17\left(\mathrm{CH}_{2}\right), 32.04$ $\left(\mathrm{CH}_{3}\right), 40.86\left(\mathrm{CH}_{2}\right), 104.95(\mathrm{CH}), 106.51\left(\mathrm{C}_{\text {arom }}\right), 115.14$ $\left(\mathrm{CH}_{2}\right), 121.14,123.62,131.36,143.80\left(5 \times \mathrm{C}_{\text {arom }}\right), 153.38$ $(\mathrm{C}=\mathrm{O}) \mathrm{ppm}$.

2,4-Dihydro-4-(2-propenyl)-5-(pyridin-2-yl)-3H-1,2,4triazol-3-one $\left(9 \mathrm{~b}, \mathrm{C}_{10} \mathrm{H}_{10} \mathrm{~N}_{4} \mathrm{O}\right)$

Yield $1.37 \mathrm{~g}$ (68\%); m.p.: $\quad 183-184{ }^{\circ} \mathrm{C}$; IR (KBr): $\bar{v}=3,180,3,014,2,953,2,814,1,964,1,640,1,454 \mathrm{~cm}^{-1}$; ${ }^{1} \mathrm{H}$ NMR $\left(300 \mathrm{MHz}\right.$, DMSO- $\left.d_{6}\right): \delta=3.50-3.59(\mathrm{~m}, 2 \mathrm{H})$, 4.11-4.77 (m, 2H), 5.11-5.16 (m, 1H), 7.02-7.30 (m, 4H, pyridine-H), $11.05(\mathrm{~s}, \mathrm{NH}) \mathrm{ppm} ;{ }^{13} \mathrm{C} \mathrm{NMR}(62.5 \mathrm{MHz}$, DMSO- $\left.d_{6}\right): \delta=39.00\left(\mathrm{CH}_{2}\right), 42.29\left(\mathrm{CH}_{2}\right), 114.71(\mathrm{CH})$, $132.20,136.00,142.62,145.61,147.47\left(6 \times \mathrm{C}_{\text {arom }}\right), 153.75$ $(\mathrm{C}=\mathrm{O}) \mathrm{ppm}$.

2,4-Dihydro-4-(2-propenyl)-5-[(pyridin-4-yl)methyl]-3H-

1,2,4-triazol-3-one $\left(\mathbf{1 0 b}, \mathrm{C}_{11} \mathrm{H}_{12} \mathrm{~N}_{4} \mathrm{O}\right)$

Yield $1.60 \mathrm{~g}$ (74\%); m.p.: $255-257{ }^{\circ} \mathrm{C}$; IR (KBr): $\bar{v}=3,180,3,065,2,790,2,654,1,703,1,639,1,457 \mathrm{~cm}^{-1}$; ${ }^{1} \mathrm{H}$ NMR $\left(300 \mathrm{MHz}\right.$, DMSO- $\left.d_{6}\right): \delta=4.25 \quad(\mathrm{~s}, \quad 2 \mathrm{H})$, 4.21-4.27 (m, 2H), 4.93-5.09 (m, 2H), 5.71-5.84 (m, 1H), 7.95-8.88 (m, 4H, pyridine-H), $11.79(\mathrm{~s}, \mathrm{NH}) \mathrm{ppm} ;{ }^{13} \mathrm{C}$ NMR $\left(62.5 \mathrm{MHz}\right.$, DMSO- $\left.d_{6}\right): \delta=29.80\left(\mathrm{CH}_{2}\right), 39.05$ $\left(\mathrm{CH}_{2}\right), 40.81\left(\mathrm{CH}_{2}\right), 115.45(\mathrm{CH}), 126.38,131.16,139.92$, $142.93\left(6 \times \mathrm{C}_{\text {arom }}\right), 154.29(\mathrm{C}=\mathrm{O}) \mathrm{ppm}$.

4-Cyclohexyl-2,4-dihydro-5-[(pyridin-4-yl)methyl]-3H-

1,2,4-triazol-3-one $\left(\mathbf{1 1 b}, \mathrm{C}_{14} \mathrm{H}_{18} \mathrm{~N}_{4} \mathrm{O}\right)$

Yield $2.06 \mathrm{~g}$ (80\%) m.p.: $237-238{ }^{\circ} \mathrm{C}$; IR $(\mathrm{KBr})$ : $\bar{v}=3,231,3,075,2,916,1,687,1,564 \mathrm{~cm}^{-1} ;{ }^{1} \mathrm{H}$ NMR (300 MHz, DMSO- $\left.d_{6}\right): \delta=0.96-2.06(\mathrm{~m}, 10 \mathrm{H}), 3.48-3.61$ $(\mathrm{m}, 1 \mathrm{H}), 4.00(\mathrm{~s}, 2 \mathrm{H}), 7.27-8.53(\mathrm{~m}, 4 \mathrm{H}$, pyridine- $\mathrm{H}), 11.48$ (s, NH) ppm; ${ }^{13} \mathrm{C}$ NMR $\left(62.5 \mathrm{MHz}\right.$, DMSO- $\left.d_{6}\right): \delta=24.53$ $\left(\mathrm{CH}_{2}\right), 25.14\left(2 \times \mathrm{CH}_{2}\right), 28.97\left(2 \times \mathrm{CH}_{2}\right), 30.94\left(\mathrm{CH}_{2}\right)$, $53.97(\mathrm{CH}), 123.92,144.96,145.06,149.74\left(6 \times \mathrm{C}_{\text {arom }}\right)$, $154.69(\mathrm{C}=\mathrm{O}) \mathrm{ppm}$.

4-(4-Ethoxyphenyl)-2,4-dihydro-5-[(pyridin-4-yl)methyl]$3 \mathrm{H}$-1,2,4-triazol-3-one $\left(\mathbf{1 2 b}, \mathrm{C}_{16} \mathrm{H}_{16} \mathrm{~N}_{4} \mathrm{O}_{2}\right)$

Yield $2.10 \mathrm{~g}$ (71\%); m.p.: $180-181{ }^{\circ} \mathrm{C}$; IR (KBr): $\bar{v}=3,231,3,074,2,917,1,678,1,475 \mathrm{~cm}^{-1} ;{ }^{1} \mathrm{H}$ NMR $\left(300 \mathrm{MHz}, \mathrm{DMSO}-d_{6}\right): \delta=1.32(\mathrm{t}, J=6.9 \mathrm{~Hz}, 3 \mathrm{H}), 3.82$ $(\mathrm{s}, 2 \mathrm{H}), 4.05(\mathrm{q}, J=6.9 \mathrm{~Hz}, 2 \mathrm{H}), 6.94-7.07(\mathrm{~m}, 4 \mathrm{H}$, phenyl-H), 7.14-8.41 (m, 4H, pyridine-H), $11.76(\mathrm{~s}, \mathrm{NH})$ ppm; ${ }^{13} \mathrm{C}$ NMR $\left(62.5 \mathrm{MHz}\right.$, DMSO- $\left.d_{6}\right): \delta=14.49\left(\mathrm{CH}_{3}\right)$, $31.23\left(\mathrm{CH}_{2}\right), 63.36\left(\mathrm{CH}_{2}\right), 114.86,124.06,124.96,128.82$, $144.42, \quad 144.99,149.22,154.54\left(12 \times \mathrm{C}_{\text {arom }}\right), 158.42$ $(\mathrm{C}=\mathrm{O}) \mathrm{ppm}$.

\section{2,4-Dihydro-5-(phenylmethyl)-4-(2-propenyl)-3H-1,2,4-} triazol-3-one $\left(\mathbf{1 3 b}, \mathrm{C}_{12} \mathrm{H}_{13} \mathrm{~N}_{3} \mathrm{O}\right)$

Yield $1.57 \mathrm{~g}$ (73\%); m.p.: $105-108{ }^{\circ} \mathrm{C}$; IR $(\mathrm{KBr})$ : $\bar{v}=3,143,3,064,2,780,1,702,1,641,1,449 \mathrm{~cm}^{-1} ;{ }^{1} \mathrm{H}$ NMR (300 MHz, DMSO- $\left.d_{6}\right): \delta=3.30-3.45(\mathrm{~m}, 2 \mathrm{H}), 4.10$ (s, 2H), 4.66-5.05 (m, 2H), 5.40-5.70 (m, 1H), 6.93-7.32 $\left(\mathrm{m}, 5 \mathrm{H}\right.$, phenyl-H), $11.64(\mathrm{~s}, \mathrm{NH}) \mathrm{ppm} ;{ }^{13} \mathrm{C}$ NMR $\left(62.5 \mathrm{MHz}, \mathrm{DMSO}-d_{6}\right): \delta=31.44\left(\mathrm{CH}_{2}\right), 40.05\left(\mathrm{CH}_{2}\right)$, $116.55\left(\mathrm{CH}_{2}\right), 126.85(\mathrm{CH}), 128.54,128.64,132.48$, $135.19,146.23\left(7 \times \mathrm{C}_{\text {arom }}\right), 154.81(\mathrm{C}=\mathrm{O}) \mathrm{ppm}$.

4,4'-(Methylenedi-4,1-phenylene)bis(5-ethyl-2,4dihydro-3H-1,2,4-triazol-3-one) $\left(\mathbf{1 5 b}, \mathrm{C}_{21} \mathrm{H}_{22} \mathrm{~N}_{6} \mathrm{O}_{2}\right)$ Yield $2.61 \mathrm{~g}$ (68\%); m.p.: $308-310^{\circ} \mathrm{C}$; IR (KBr): $\bar{v}=3,176,3,066,2,955,1,698,1,580,1,417 \mathrm{~cm}^{-1} ;{ }^{1} \mathrm{H}$ NMR $\left(300 \mathrm{MHz}\right.$, DMSO- $\left.d_{6}\right): \delta=1.00(\mathrm{t}, J=4.6 \mathrm{~Hz}$, $6 \mathrm{H}), 2.36(\mathrm{q}, J=7.4 \mathrm{~Hz}, 4 \mathrm{H}), 3.32(\mathrm{~s}, 2 \mathrm{H}), 7.05-7.94(\mathrm{~m}$, 8H, phenyl-H), 11.59 (s, 2NH) ppm; ${ }^{13} \mathrm{C}$ NMR $(62.5 \mathrm{MHz}$, DMSO- $\left.d_{6}\right): \delta=8.30\left(2 \times \mathrm{CH}_{3}\right), 17.92\left(2 \times \mathrm{CH}_{2}\right), 39.05$ $\left(\mathrm{CH}_{2}\right), \quad 126.05, \quad 128.32,139.98 \quad\left(14 \times \mathrm{C}_{\text {arom }}\right), \quad 146.54$ $(2 \times \mathrm{C}=\mathrm{O}) \mathrm{ppm}$.

\section{$U V$-Vis spectroscopy}

UV-Vis spectra were recorded in water (buffer)-methanol (1:1) solution on a UV-160A Shimadzu Spectrophotometer. Quartz cuvettes $(1 \mathrm{~cm})$ were used for measurements.

\section{Liquid chromatography}

HPLC was carried out using a liquid chromatograph (Knauer, Berlin, Germany) with a dual pump, a $20-\mathrm{mm}^{3}$ simple injection valve and a UV-visible detector at $254 \mathrm{~nm}$. The samples were prepared as solutions in methanol.

\section{RP-8 chromatography}

A Hypersil MOS2 C8 $(5 \mu \mathrm{m}, 150 \times 4.6 \mathrm{~mm})$ column was used as the stationary phase. The mobile phase consisted of different volume mixtures of methanol and $20 \mathrm{mM}$ acetate buffer $(\mathrm{KCl})$ as the aqueous phase to give $\mathrm{pH}$ 7.4. The methanol concentration ranged from 0.10 to 0.70 at 0.1 (0.05) intervals. The flow rate was $1 \mathrm{~cm}^{3} \mathrm{~min}^{-1}$ at room temperature. The retention time of an unretained solute $\left(t_{0}\right)$ was determined by the injection of a small amount of acetone dissolved in water. 


\section{RP-18 chromatography}

A Hypersil Gold C18 $(3 \mu \mathrm{m}, 100 \times 3 \mathrm{~mm})$ column was used as the stationary phase. The mobile phase consisted of different volume mixtures of methanol and $20 \mathrm{mM}$ phosphate buffer as the aqueous phase to give $\mathrm{pH}$ 7.4. The methanol concentration ranged from 0.30 to 0.75 , depending on the structure of compound, at $0.05(0.1)$ intervals. The flow rate was $0.5 \mathrm{~cm}^{3} \mathrm{~min}^{-1}$ at room temperature. The retention time of an unretained solute $\left(t_{0}\right)$ was determined by the injection of a small amount of acetone dissolved in water.

\section{IAM chromatography}

A Rexchrom IAM.PC.DD2 $(12 \mu \mathrm{m}, 100 \times 4.6 \mathrm{~mm}$, $300 \AA$ ) (Regis Technologies) column was used as the stationary phase. The mobile phase consisted of different volume mixtures of acetonitrile and $20 \mathrm{mM}$ phosphate buffer as the aqueous phase to give $\mathrm{pH} 7.4(0.02 \mathrm{M}$ $\mathrm{KH}_{2} \mathrm{PO}_{4}, \mathrm{Na}_{2} \mathrm{HPO}_{4}$, and $0.15 \mathrm{M} \mathrm{KCl}$ ). The acetonitrile concentration ranged from 0 to 0.50 , depending on the structure of compound, at 0.05 intervals. The flow rate was $1 \mathrm{~cm}^{3} \mathrm{~min}^{-1}$ at room temperature. The retention time of an unretained solute $\left(t_{0}\right)$ was determined by the injection of a small amount of citric acid dissolved in water [36, 37].

\section{Computational methods}

The 3D structure of each compound was built up from the fragment library in the PC SPARTAN Pro ver 1.08 molecular modeling program, and it was fully geometryoptimized at the semi-empirical PM3 level [38]. The energy-minimized structure was subjected to conformational analysis implemented in SPARTAN. Conformational analysis was carried out through systemic conformation option. The conformers of the lowest energy were compared. The $\log P$ values were calculated using ChemDraw Ultra 10.0 [39].

\section{Statistic analysis}

The coefficients in the regression equations were calculated by the multiple regression analysis program Statistica, version 7.1 [40]. Statistical significance of the regression equation was tested by the correlation coefficient $(r)$, the standard error of estimate $(s)$ and the variance ratio $(F)$ at specified degrees of freedom $(d f), n$ number of compounds.

Open Access This article is distributed under the terms of the Creative Commons Attribution License which permits any use, distribution, and reproduction in any medium, provided the original author(s) and the source are credited.

\section{References}

1. Aher NG, Pore VS, Mishra NN, Kumar A, Shukla PK, Sharma A, Bhat MK (2009) Bioorg Med Chem Lett 19:759

2. Bhat AR, Bhat GV, Shenoy GG (2001) J Pharm Pharmacol 53:267

3. Trzaskos JM, Bowen WD, Shafiee A, Fischer RT, Gaylor JL (1984) J Biol Chem 259:13402

4. Demirbas N, Ugurlouglu SA, Demirbas A (2002) Biorg Med Chem 10:3717

5. Yüksen H, Demirbaş A, Ikizler A, Johansson CB, Celik C, Ikizler AA (1997) Arzneim Forsch 47:405

6. Hui XP, Zhang L, Zhang ZY, Wang Q, Wang F (2000) J Chin Chem Soc 47:535

7. Trsukuda T, Shiratoi Y, Watanabe M, Ohtsuka H, Hattori K, Shirai M, Shimma N (1998) Bioorg Med Chem Lett 8:1819

8. Witoaski JT, Robins RK, Sidwel RW, Simon LN (1972) J Med Chem 15:1150

9. Kritsanida M, Mouroutsou A, Marakos P, Pouli N, Papakonstantinou-Garoufalias S, Pannecougue C, Witvouw M, De Clerq E (2002) Il Farmaco 57:253

10. Walczak K, Gondela A, Suwiński J (2004) Eur J Med Chem 39:849

11. Amir M, Shikha K (2004) Eur J Med Chem 39:535

12. Shiradkar MR, Ahivaprasadh N (2006) Asian J Chem 18:319

13. Pitucha M, Chodkowska A, Maciejewski M, Jagiełło-Wójtowicz E, Pachuta-Stec A (2010) Monatsh Chem 141:199

14. Valko K, Sleger P (1993) J Chromatogr A 669:346

15. Valko K (2004) J Chromatogr A 1037:299

16. Kaliszan R, Nasal A, Markuszewski MJ (2003) Anal Bioanal Chem 377:803

17. Matysiak J, Niewiadomy A, Mącik-Niewiadomy G (2000) Eur J Pharm Sci 10:119

18. Ong S, Liu H, Qui X, Bhat G, Pidgeon C (1995) Anal Chem 67:755

19. Nasal A, Sznitowska M, Bucinski A, Kaliszan R (1995) J Chromatogr A 692:83

20. Pidgeon C, Venkataram UV (1989) Anal Biochem 176:36

21. Soczewiński E, Wachtmeister CA (1962) J Chromatogr A 7:311

22. Snyder LR, Dolan JW, Gant JR (1979) J Chromatogr A 165:3

23. Hollósy F, Lorand T, Örfi L, Erös D, Kéri G, Idei M (2002) J Chromatogr B 768:361

24. Kaliszan R (1987) Quantitative structure-chromatographic retention relationship. Jon Wiley \& Sons, New York

25. Biagi GL, Barbaro AM, Sapone A, Recanatini (1994) J Chromatogr A 669:246

26. Todeschini R, Consonni V (2009) Molecular descriptors for chemoinformatics; methods and principles in medicinal chemistry, vol 41. Wiley-VCH, Weinheim

27. Ghose AK, Crippen GM (1987) J Chem Inf Comput Sci 27:21

28. Ward RS, Davies J, Hodges G, Roberts DW (2003) J Chromatogr A 1007:67

29. Abraham MH, Chadha HS, Leitao RAE, Mitchell RC, Lambert WJ, Kaliszan R, Nasal A, Haber P (1997) J Chromatogr A 766:35

30. Kaliszan R (1999) Trends Anal Chem 18:400

31. Pitucha M, Polak B, Świeboda R, Kosikowska U, Malm A (2009) Z Naturforsch 64b:570

32. Pitucha M, Olender A, Wujec M, Borowski P, Mardarowicz M (2010) J Chin Soc 57:260

33. Pitucha M, Borowski P, Karczmarzyk Z, Fruziński A (2009) J Mol Struct 919:170

34. Ismail I, Imam I, El-Azeem AH, Abd A (1995) Chem Chem Eng 39:19

35. Pitucha M, Karczmarzyk Z, Kosikowska U, Malm A (2011) Z Naturforsch 66b:505 
36. Ward RS, Davies J, Hodges G, Roberts DW (2003) J Chromatogr A 1007:67

38. PC Spartan Pro (1999) Wavefunction Inc, California

39. ChemOffice (2006) CambridgeSoft Corporation, Cambridge

37. Taillardat-Bertschinger A, Galland A, Carrupt PA, Testa B (2002) J Chromatogr A 953:39

40. Statistica 7.1 (2005) StatSoft Inc, Tulsa 